\title{
Solute Uptake by Dictyostelium discoideum and its Inhibition
}

\author{
By MICHAEL J. NORTH \\ Department of Biological Science, University of Stirling, Stirling FK9 4LA, U.K.
}

(Received 6 September 1982; revised 13 October 1982)

\begin{abstract}
A study has been made of the uptake of radioactively-labelled solutes by starved myxamoebae of the cellular slime mould Dictyostelium discoideum. Inulin uptake was energy-dependent, inhibited by cycloheximide, and the rate was proportional to extracellular inulin concentration. The ability of the cells to take up inulin did not change during starvation. Uptake of four other solutes, $\beta$-alanine, glucose, protein hydrolysate and uracil occurred at a similar rate to inulin uptake when expressed as an endocytic index ( $\mu \mathrm{l}$ medium taken up $\mathrm{h}^{-1}$ per $10^{6}$ cells). All the results were consistent with uptake occurring by fluid-phase pinocytosis. Pinocytic activity thus occurred in starving cells and was found to be affected by some agents that act as developmental inhibitors. Uptake of inulin and putrescine (previously shown to be taken up by adsorptive pinocytosis) was inhibited by chloroquine, $\mathrm{KCl}$ and $\mathrm{NH}_{4} \mathrm{Cl}$, although ammonium ions also blocked developmental changes in the ability of myxamoebae to take up putrescine. Sodium ions were less inhibitory. $\varepsilon$-Aminocaproic acid inhibited solute uptake in a temperaturedependent, reversible manner.
\end{abstract}

\section{INTRODUCTION}

The mechanism of solute uptake by the cellular slime mould Dictyostelium discoideum has received very little attention despite the widespread use of soluble nutrients, metabolic inhibitors and radioactively-labelled precursors, all of which must enter the cells during experimental procedures. Although some workers have stated that uptake of extracellular materials occurs exclusively by endocytic processes (phagocytosis and pinocytosis), few supporting data have yet been published. In a previous paper (Turner et al., 1979) we reported that the uptake of putrescine (1,4-diaminobutane) by myxamoebae of $D$. discoideum could be accounted for in terms of adsorptive pinocytosis at low solute concentrations, with fluid-phase pinocytosis contributing at higher concentrations. However, rates of putrescine uptake are atypically high when compared with those of other solutes in D. discoideum and in this paper data on the uptake of other solutes are reported. These are shown to be consistent with fluidphase pinocytosis as the major uptake mechanism.

Results are also presented on the effect on solute uptake of a number of agents used in in vivo studies on $D$. discoideum. This was prompted by the earlier observation that $\varepsilon$-aminocaproic acid (EACA), an inhibitor of development (North \& Ashworth, 1976; North \& Campbell, 1976), decreased the rate of putrescine uptake (Turner et al., 1979). In this study some of the characteristics of the inhibition of solute uptake by EACA were examined and the effects of monovalent cations and chloroquine are also described.

\section{METHODS}

Measurement of uptake rates. Myxamoebae of the axenic strain AX2 (ATCC 24397) were grown at $22^{\circ} \mathrm{C}$ in HL5 medium with no added sugar, as described by Watts \& Ashworth (1970). When they had reached a density of approximately $2 \times 10^{6}$ cells $\mathrm{ml}^{-1}$ they were harvested by centrifugation, washed once with water and finally

Abbreviation: EACA, $\varepsilon$-aminocaproic acid. 
resuspended in $17 \mathrm{~mm}$-sodium phosphate buffer $\left(\mathrm{pH} \mathrm{6.0)}\right.$ at $1 \times 10^{7}$ cells $\mathrm{ml}^{-1}$ except for measurements of putrescine uptake when a lower density of $2.5 \times 10^{6}$ cells $\mathrm{ml}^{-1}$ was used. Unless otherwise indicated $10 \mathrm{ml}$ suspensions were incubated in $50 \mathrm{ml}$ Erlenmeyer flasks. After a preincubation period of between 15 and $120 \mathrm{~min}$, radioactively-labelled solute was added to the suspension. Except when putrescine was used at a high concentration $(2.5 \mathrm{~mm})$, no unlabelled solute was included; thus all solutes were present at micromolar or nanomolar concentrations. The concentration of radioactivity was $0 \cdot 01 \mu \mathrm{Ci} \mathrm{ml}^{-1}$ for putrescine and $0 \cdot 1 \mu \mathrm{Ci} \mathrm{ml} l^{-1}$ for other solutes. During the preincubation and the sampling periods cells were shaken in an orbital incubator at 130 r.p.m., and unless otherwise indicated the temperature was $24^{\circ} \mathrm{C}$. Solute uptake was followed by measuring radioactivity in washed centrifuged cell pellets as described previously for putrescine (Turner et al., 1979) and the initial rate calculated. The sampling period was up to $40 \mathrm{~min}$ for putrescine and up to $240 \mathrm{~min}$ for other solutes. Whenever inulin was used the washed cell pellets were dissolved overnight in $0.3 \mathrm{ml}$ of NCS tissue solubilizer before transfer to scintillation vials, addition of scintillation fluid and counting. All other cell samples were transferred and counted immediately after sampling.

Chemicals. $\beta$-[3-14 C]Alanine $\left(8.5 \mathrm{mCi} \mathrm{mmol}^{-1} ; 1 \mathrm{mCi}=37 \mathrm{MBq}\right), \mathrm{D}-\left[\mathrm{U}-{ }^{14} \mathrm{C}\right] \mathrm{glucose}\left(284 \mathrm{mCi} \mathrm{mmol}^{-1}\right)$, $\left[{ }^{3} \mathrm{H}\right]$ inulin $\left(1.9 \mathrm{Ci} \mathrm{mmol}^{-1}\right.$, average molecular weight approx. 5200$)$, [U-14 $\left.\mathrm{C}\right]$ protein hydrolysate $(54 \mathrm{mCi}$ milliatom $\left.{ }^{-1}\right),\left[1,4-^{-14} \mathrm{C}\right]$ putrescine dihydrochloride $\left(116 \mathrm{mCi} \mathrm{mmol}^{-1}\right)$ and $[5-3 \mathrm{H}]$ uracil $\left(27 \mathrm{Ci} \mathrm{mmol}^{-1}\right)$ were all purchased from Amersham. EACA and $\beta$-alanine were supplied by Sigma, and inulin by BDH. $p$-Aminomethylbenzoic acid was a gift from VEB Arzneimittelwerk, Dresden, G.D.R. NCS tissue solubilizer was obtained from Amersham/Searle. All other chemicals were of the highest purity commercially available.

\section{RESULTS AND DISCUSSION}

\section{Solute uptake rates}

In the experiments reported here, solute uptake rates were measured in suspensions of myxamoebae starved in sodium phosphate buffer, a system used in some previous studies on uptake in D. discoideum (Lee, 1972; North \& Williams, 1978; Turner et al., 1979). Although this system is one in which uptake may not be of major physiological importance (the myxamoebae are not feeding at this stage), it has the advantage over the use of suspensions of growing cells in that it avoids complex media whose precise composition, including concentrations of factors which might influence uptake rates, could vary from one experiment to another. As the results below indicate, solute uptake did occur in starving cells.

In most of the experiments two solutes in particular, $\left[1,4-{ }^{14} \mathrm{C}\right]$ putrescine and $\left[{ }^{3} \mathrm{H}\right]$ inulin, were used. As previously reported (Turner et al., 1979), putrescine uptake rates were always considerably greater than those of other solutes. At a concentration of $1 \mu \mathrm{M}$, for example, it was taken up at a rate equivalent to the uptake of $50 \mu \mathrm{l}$ medium $\mathrm{h}^{-1}$ per $10^{6}$ cells. These greater rates have been interpreted in terms of adsorptive pinocytosis (Turner et al., 1979).

Although it has been reported that inulin does not penetrate cells during short incubation periods (Wick et al., 1978), a significant labelling of cells with $\left[{ }^{3} \mathrm{H}\right]$ inulin was observed in the present experiments (Fig. 1) in agreement with the findings of Lee (1972). This labelling was inhibited completely by $0.1 \mathrm{~mm}$-dinitrophenol and $1 \mathrm{~mm}$-sodium azide. It was not possible to remove the radioactivity from the cells by additional washing with water or with salts solution and so labelling was considered to represent the uptake of inulin into the cells. As with the uptake of EACA (North \& Williams, 1978), inulin uptake was inhibited by cycloheximide (Fig. 1) indicating a possible dependence on protein synthesis. The uptake rate (expressed as ng inulin taken up $\mathrm{h}^{-1}$ per $10^{6}$ cells) was directly proportional to inulin concentration over the wide range tested. At all inulin concentrations and with cell densities up to $1.8 \times 10^{7}$ cells $\mathrm{ml}^{-1}$ (the maximum density used), labelled inulin uptake was linear for at least $2 \mathrm{~h}$. Labelling of cells was normally started after the cells had starved for $2 \mathrm{~h}$ but the ability to take up inulin did not change during at least the first $10 \mathrm{~h}$ of incubation in phosphate buffer.

Additional measurements were made with other solutes, namely $\beta$-alanine, glucose, protein hydrolysate and uracil. Together with inulin these represented a diverse group in terms of their structure, properties and intracellular fate. For all of these solutes the labelling of cells was linear for at least $1 \mathrm{~h}$. It was also inhibited by $1 \mathrm{~mm}$-sodium azide. The rate of labelling was not affected by the addition of unlabelled solute to the radioactively-labelled material. These observations were consistent with labelling due to a non-saturable, energy-dependent mechanism. When 

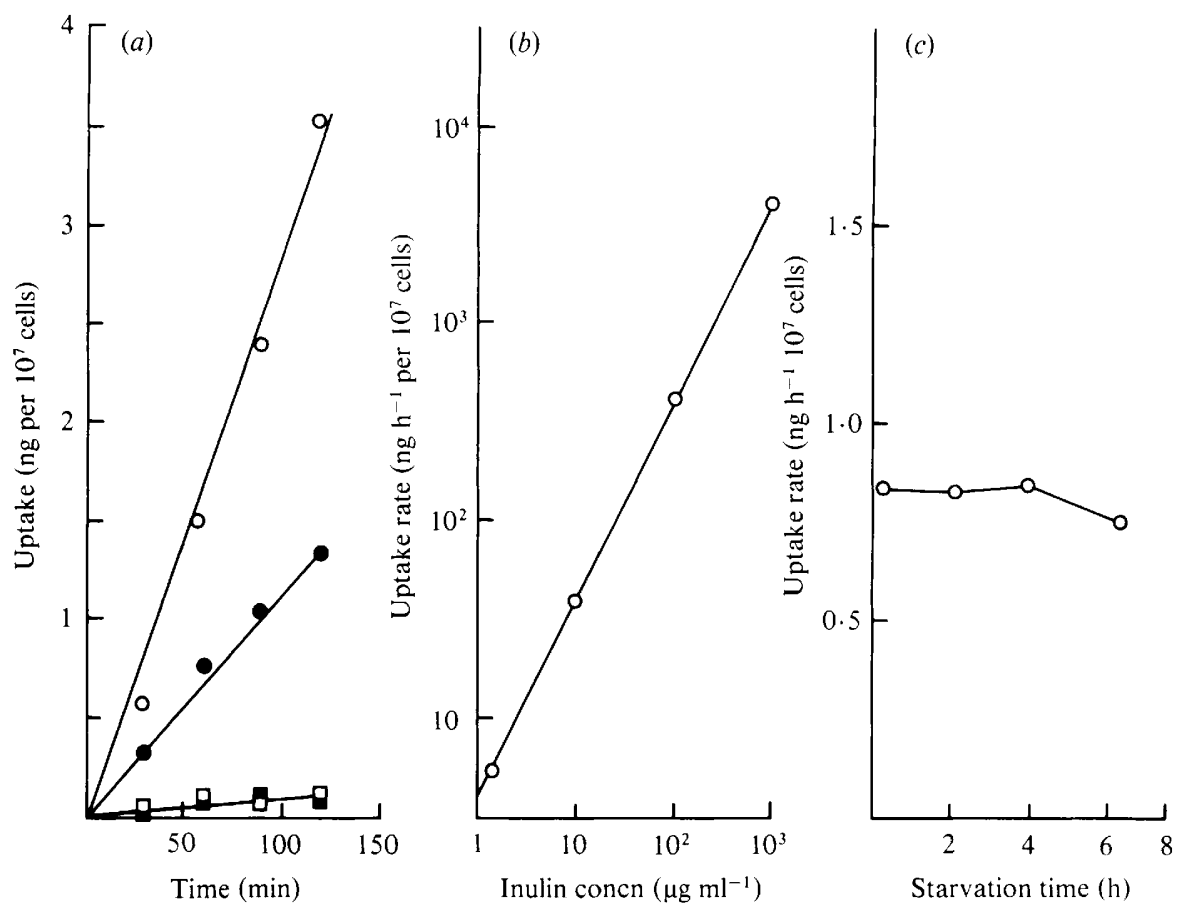

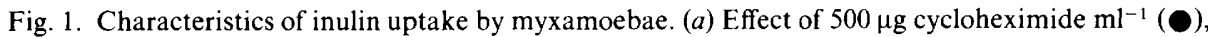
$0.1 \mathrm{~mm}$-dinitrophenol $(\square)$, and $1 \mathrm{~mm}$-sodium azide ( $\square$ ) on inulin uptake; $O$, control cells. (b) Effect of inulin concentration on uptake rate. (c) Effect of time of starvation on inulin uptake rate. The cells used in $(a)$ and $(b)$ were starved for $2 \mathrm{~h}$ before addition of inulin.

\section{Table 1. Rates of uptake of radioactively-labelled solutes}

Initial rates of uptake were measured in suspensions of myxamoebae harvested $2 \mathrm{~h}$ before addition of radioactively-labelled solute and are expressed as endocytic indices. Results are given as means \pm S.D. The number of determinations is indicated in parentheses.

\begin{tabular}{lcc}
\multicolumn{1}{c}{ Solute } & $\begin{array}{c}\text { Solute concn } \\
(\mu \mathrm{M} \text { unless } \\
\text { indicated otherwise })\end{array}$ & $\begin{array}{c}\text { Endocytic index } \\
\left(\mu 1 \mathrm{~h}^{-1} \text { per } 10^{6} \text { cells }\right)\end{array}$ \\
$\beta$-Alanine & 12.0 & $0.28 \pm 0 \cdot 14(5)$ \\
Glucose & 0.35 & $0.40 \pm 0 \cdot 15(5)$ \\
Inulin & $0.33 \mu \mathrm{g} \mathrm{ml}^{-1}$ & $0.40 \pm 0.17(14)$ \\
Protein hydrolysate & $1.85 \mu$ atom carbon $\mathrm{l}^{-1}$ & $0.57 \pm 0.25(5)$ \\
Uracil & 0.004 & $0.54 \pm 0.19(5)$
\end{tabular}

uptake rates were expressed in terms of an endocytic index (Williams et al., 1975) similar values were obtained (Table 1). Although there were differences in rates between one batch of cells and another, every determination of the endocytic index with these solutes gave a value within the range $0 \cdot 2-0 \cdot 8 \mu 1$ medium $^{-1}$ per $10^{6}$ cells. Previous data for EACA uptake (North \& Williams, 1978) were also in this range. More recently, Thilo \& Vogel (1980) have reported the rate of uptake of FITC-dextran by $D$. discoideum myxamoebae in HL5 growth medium to be $0.014 \mu \mathrm{l}$ medium $\min ^{-1}$ per $10^{6}$ cells, i.e. $0.84 \mu \mathrm{h} \mathrm{h}^{-1}$ per $10^{6}$ cells, a rate similar to those reported here. The similarities between uptake rates suggest a common mechanism for all of the solutes. Fluidphase pinocytosis would provide such a mechanism. Any other mechanisms can only make a minor contribution to the uptake of particular solutes under the conditions used.

In terms of solute taken up per cell the rates determined in this study are similar to those reported for fluid-phase pinocytosis in mammalian cells (Kaplan \& Nielsen, 1978; Pratten et al., 1977; Ose et al., 1980), although direct comparisons are difficult because of differences in the 
size and surface area of the cells concerned. Bowers (1977) has reported a rate of $3 \mu 1$ medium h$^{-1}$ per $10^{6}$ cells for $\left[{ }^{3} \mathrm{H}\right]$ inulin uptake by the protozoan Acanthamoeba castellanii. Although this is higher than the rates measured here, the abilities of $A$. castellanii and $D$. discoideum to take up solute by fluid-phase pinocytosis are comparable since the former cells are larger [mean cell volume $4000 \mu \mathrm{m}^{3}$ (Bowers, 1977)] than the latter [mean cell volume $650 \mu \mathrm{m}^{3}$ (Cappuccinelli \& Ashworth, 1976)].

Although the rates of pinocytosis are similar to those of other types of cell, they do represent a somewhat slow rate of accumulation of material from the external environment. Assuming a mean cell volume of $650 \mu \mathrm{m}^{3}$ (Cappuccinelli \& Ashworth, 1976) the uptake of solute contained within a volume of medium equivalent to that of the cells, required, on average, approximately $1.5 \mathrm{~h}$. This low rate of accumulation of extracellular solute may be significant when the incorporation of radioactively-labelled precursors into cellular material is measured, since entry into the cells could in some cases be the rate-limiting step. In the present study the axenic strain AX2 was used and it is worth noting that solute uptake was significantly greater in this strain than in slower-growing axenic strains and non-axenic strains (North \& Williams, 1978).

\section{Inhibition of solute uptake}

Some agents that have been used in in vivo studies on $D$. discoideum were tested for their effect on solute uptake (Table 2). Uptake was affected by the ionic environment of the cells. Addition of $\mathrm{KCl}$ to the buffer inhibited the uptake of both putrescine (due to adsorptive pinocytosis) and inulin (due to fluid-phase pinocytosis), the effect being greater when the cells were preincubated with $\mathrm{KCl}$ prior to addition of the labelled solute. In contrast $\mathrm{NaCl}$ had no significant effect on putrescine uptake. It did inhibit inulin uptake when added at the same time as inulin but the effect was considerably less when the cells had been preincubated with $\mathrm{NaCl}$. $\mathrm{KCl}$, but not $\mathrm{NaCl}$, has been shown to inhibit developmentally-related events in starving myxamoebae and this may be the result of a deleterious effect on the transmembrane potential (Marin \& Rothman, 1980). Membrane depolarization might also influence the ability of the cells to carry out pinocytosis. The effect of $\mathrm{NH}_{4} \mathrm{Cl}$ was more complex. It was a severe inhibitor of inulin uptake, although the effect was reduced if the cells were preincubated with $\mathrm{NH}_{4} \mathrm{Cl}$. Putrescine uptake was also inhibited when $\mathrm{NH}_{4} \mathrm{Cl}$ was added simultaneously with putrescine, but when added immediately after the cells had been harvested, and $2 \mathrm{~h}$ prior to the addition of putrescine, $\mathrm{NH}_{4} \mathrm{Cl}$ apparently enhanced the rate of putrescine uptake. The ability of the cells to take up putrescine normally decreases during starvation of the myxamoebae (Turner et al., 1979) and further analysis showed that $\mathrm{NH}_{4} \mathrm{Cl}$ had in fact prevented this from taking place. The decrease is believed to be due to developmentally-regulated changes at the cell surface (Turner et al., 1979) and the effect of $\mathrm{NH}_{4} \mathrm{Cl}$ observed here might be related to other effects of ammonia on $D$. discoideum at other stages of development (Kay, 1979; Schindler \& Sussman, 1977).

Chloroquine affects pinocytosis in some animal systems (Gonzalez-Noriega et al., 1980; Tietze et al., 1980) and has recently been reported to inhibit phagocytosis of yeast by $D$. discoideum (Favard-Séréno et al., 1981). It was a severe inhibitor of both putrescine uptake and inulin uptake (Table 2). Fong \& Bonner (1979) have shown that chloroquine blocks development of $D$. discoideum, although this effect was attributed to inhibition of proteolytic activity since it could be reversed by the provision of amino acids.

The results in Table 2 also confirm the inhibition of putrescine uptake by EACA, an inhibitor of development (North \& Ashworth, 1976; North \& Campbell, 1976), and show that a similar effect could be seen with other solutes, indicating that the inhibition was not specific for adsorptive pinocytosis. There were, however, differences between the degree of inhibition for the various solutes, particularly for glucose whose uptake was consistently less affected by EACA. This would not be expected if all solutes were taken up by an identical mechanism and EACA were solely affecting this mechanism. It would appear, therefore, that additional factors are involved in glucose uptake. Preincubation of the cells with EACA enhanced its effect on solute uptake, an observation consistent with a need for EACA to enter the cells. $p$ Aminomethylbenzoic acid, which like EACA inhibits the development of $D$. discoideum (North $\&$ Ashworth, 1976), also inhibited solute uptake but was less effective than EACA. $\beta$-Alanine, however, did not decrease the rate of solute uptake. The inhibitory effect of EACA was greater 
Table 2. Effect of various agents on solute uptake rates

Initial uptake rates were measured in suspensions of myxamoebae incubated for $2 \mathrm{~h}$ before addition of radioactively-labelled solute. Putrescine was added at a concentration of $0 \cdot 10 \mu \mathrm{M}$, all other solute concentrations were as in Table 1 . The other additions were made either $2 \mathrm{~h}$ before or at the same time as the labelled solute. Rates are given relative to those of control suspensions (rate $=1 \cdot 0$ ) to which no addition was made, and they represent the average from at least two experiments.

\begin{tabular}{|c|c|c|c|c|}
\hline \multirow[b]{2}{*}{ Solute } & \multirow[b]{2}{*}{ Additive } & \multirow[b]{2}{*}{$\begin{array}{l}\text { Additive } \\
\text { concn (mM) }\end{array}$} & \multicolumn{2}{|c|}{$\begin{array}{l}\text { Relative uptake rates with } \\
\text { additive added: }\end{array}$} \\
\hline & & & $\begin{array}{c}2 \mathrm{~h} \\
\text { before solute }\end{array}$ & $\begin{array}{c}\text { At same } \\
\text { time as solute }\end{array}$ \\
\hline \multirow[t]{5}{*}{ Inulin } & $\mathrm{KCl}$ & 50 & 0.27 & 0.49 \\
\hline & $\mathrm{NaCl}$ & 50 & $0 \cdot 80$ & $0 \cdot 34$ \\
\hline & $\mathrm{NH}_{4} \mathrm{Cl}$ & 50 & $0 \cdot 58$ & $0 \cdot 16$ \\
\hline & Chloroquine & $2 \cdot 5$ & ND & 0.43 \\
\hline & EACA & 50 & 0.08 & $0 \cdot 24$ \\
\hline \multirow[t]{5}{*}{ Putrescine } & $\mathrm{KCl}$ & 50 & $0 \cdot 30$ & $0 \cdot 90$ \\
\hline & $\mathrm{NaCl}$ & 50 & 0.92 & 0.91 \\
\hline & $\mathrm{NH}_{4} \mathrm{Cl}$ & 50 & $2 \cdot 48$ & 0.45 \\
\hline & Chloroquine & $2 \cdot 5$ & $0 \cdot 15$ & $0 \cdot 15$ \\
\hline & $\mathrm{EACA}$ & 50 & $0 \cdot 25$ & $1 \cdot 40$ \\
\hline$\beta$-Alanine & EACA & 50 & $0 \cdot 23$ & $0 \cdot 29$ \\
\hline Glucose & EACA & 50 & 0.82 & $1 \cdot 02$ \\
\hline Protein hydrolysate & EACA & 50 & $0 \cdot 33$ & 0.47 \\
\hline Uracil & EACA & 50 & $0 \cdot 27$ & $0 \cdot 72$ \\
\hline
\end{tabular}

ND, Not determined.

at higher temperatures. At $19{ }^{\circ} \mathrm{C}$ the rate of inulin uptake for a cell suspension incubated with $50 \mathrm{mM}-\mathrm{EACA}$ was $45 \%$ of that for a control suspension incubated identically but without EACA. At $24{ }^{\circ} \mathrm{C}$, however, the rate for EACA-treated cells was $6 \%$ of that for a control suspension. Putrescine uptake was in fact slightly enhanced by the presence of $50 \mathrm{mM}$-EACA at $19{ }^{\circ} \mathrm{C}$ but at $24{ }^{\circ} \mathrm{C}$ the uptake rate for EACA-treated cells was reduced to $25 \%$ of that for a control suspension. All of these effects could be reversed by switching the incubation temperature of EACA-treated cells prior to addition of labelled solute. The characteristics of the temperature dependence were similar to those observed for the effect of temperature on the inhibition of development by EACA (North \& Ashworth, 1976). The inhibition of solute uptake could also be reversed simply by centrifuging the cells and resuspending them in EACA-free buffer.

Starving cells of $D$. discoideum were able to take up solutes by pinocytosis. It is unlikely that this pinocytic activity was triggered as a consequence of adding low concentrations of labelled solutes to the cells and the activity must be an inherent property of developing cells, at least under these conditions. At this stage of the life cycle pinocytosis would not be needed for nutrient uptake and so it may occur as the result of membrane cycling necessary for other cellular functions. The fact that some developmental inhibitors affect pinocytosis does not establish a role for pinocytosis in development but could be a reflection of their effect on other essential membrane functions. The results show that certain inhibitors can affect the uptake of labelled precursors and so perhaps obscure other effects of the inhibitors on intracellular processes. An understanding of how solutes enter myxamoebae and the factors affecting pinocytosis is therefore clearly of importance.

This work was supported by a grant from the Science and Engineering Research Council. I wish to thank Jennifer Harwood for excellent technical assistance.

\section{REFERENCES}

Bowers, B. (1977). Comparison of pinocytosis and phagocytosis in Acanthamoeba castellani. Experimental Cell Research 110, 409-417.
CAPPuccinelli, P. \& Ashworth, J. M. (1976). The effect of inhibitors of microtubule and microfilament function on the cellular slime mould Dictyo- 
stelium discoideum. Experimental Cell Research 103, 387-393.

FAVARD-SÉréno, C., Ludosky, M.-A. \& Ryter, A. (1981). Freeze-fracture study of phagocytosis in Dictyostelium discoideum. Journal of Cell Science 51, 63-84.

Fong, D. \& Bonner, J. T. (1979). Proteases in cellular slime mold development: evidence for their involvement. Proceedings of the National Academy of Sciences of the United States of America 76, 64816485 .

Gonzalez-Noriega, A., Grubb, J. H., Talkad, V. \& SLY, W. S. (1980). Chloroquine inhibits lysosomal enzyme pinocytosis and enhances lysosomal enzyme secretion by impairing receptor recycling. Journal of Cell Biology 85, 839-852.

Kaplan, J. \& Nielsen, M. (1978). Pinocytic activity of rabbit alveolar macrophages in vitro. Journal of the Reticuloendothelial Society 24, 673-685.

KAY, R. R. (1979). Gene expression in Dictyostelium discoideum: mutually antagonistic role of cyclicAMP and ammonia. Journal of Embryology and Experimental Morphology 52, 171-182.

LEE, K.-C. (1972). Permeability of Dictyostelium discoideum towards amino acids and inulin: a possible relationship between initiation of differentiation and loss of 'pool' metabolites. Journal of General Microbiology 72, 457-471.

Marin, F. T. \& Rothman, F. G. (1980). Regulation of development in Dictyostelium discoideum. IV. Effects of ions on the rate of differentiation and cellular response to cyclic AMP. Journal of Cell Biology 87, 823-827.

North, M. J. \& Ashworth, J. M. (1976). Inhibition of the development of the cellular slime mould Dictyostelium discoideum by $\omega$-aminocarboxylic acids. Journal of General Microbiology 96, 63-75.

NorTh, M. J. \& Campbell, A. J. (1976). The effect of $\varepsilon$-aminocaproic acid on biochemical changes in the development of the cellular slime mould Dictyostelium discoideum. Journal of General Microbiology 96, 77-85.

North, M. J. \& Williams, K. L. (1978). Relationship between the axenic phenotype and sensitivity to $\omega$ aminocarboxylic acids in Dictyostelium discoideum. Journal of General Microbiology 107, 223-230.

Ose, L., Ose, T., Reinertsen, R. \& Berg, T. (1980). Fluid endocytosis in rat parenchymal and nonparenchymal liver cells. Experimental Cell Research 126, 109-119.

Pratten, M. K., Williams, K. E. \& Lloyd, J. B. (1977). A quantitative study of pinocytosis and intracellular proteolysis in rat peritoneal macrophages. Biochemical Journal 168, 365-372.

SCHINDleR, J. \& Sussman, M. (1977). Ammonia determines the choice of morphogenetic pathways in Dictyostelium discoideum. Journal of Molecular Biology 116, 161-169.

Thilo, L. \& Vogel, G. (1980). Kinetics of membrane internalization and recycling during pinocytosis in Dictyostelium discoideum. Proceedings of the National Academy of Sciences of the United States of America 77, 1015-1019.

Tietze, C., Schlesinger, P. \& Stahl, P. (1980). Chloroquine and ammonium ion inhibit receptormediated endocytosis of mannose-glycoconjugates by macrophages: apparent inhibition of receptor recycling. Biochemical and Biophysical Research Communications 93, 1-8.

Turner, R., NorTh, M. J. \& Harwood, J. M. (1979). Putrescine uptake by the cellular slime mould Dictyostelium discoideum. Biochemical Journal 180, 119-127.

WatTS, D. J. \& Ashworth, J. M. (1970). Growth of myxamoebae of the cellular slime mould Dictyostelium discoideum in axenic culture. Biochemical Journal 119, 171-174.

Wick, U., Malchow, D. \& Gerisch, G. (1978). Cyclic-AMP stimulated calcium influx into aggregating cells of Dictyostelium discoideum. Cell Biology International Reports 2, 71-79.

Williams, K. E., Kidston, E. M., BECK, F. \& Lloyd, J. B. (1975). Quantitative studies of pinocytosis. 1. Kinetics of uptake of $\left[{ }^{125} \mathrm{I}\right]$ polyvinylpyrrolidone by rat yolk sac cultures in vitro. Journal of Cell Biology 64, 113-122. 